\title{
ASSESSMENT OF FAUNAL DIVERSITY OF A NATURAL FOREST AND AN ADJACENT PINUS MIXED PLANTATION FOREST IN YAGIRALA
}

\author{
M M A I Janaka' and Sriyanie Miththapala² \\ 'Department of Forestry and Environment science, University of Sri Jayewardenepura \\ 2Ladies College, Colombo.
}

Fatumal diversity of the natural forest (Pamaragala Aranya Forest) and the Universily of Sri Jayewardencpura Pinus-mixed forest, in Yagirala forest reserve was assessed. The University Pinus - mixed forest hass a dense undergrowth and tropical lowland tree species. The natural forest is a highly degraded lorest due to past logging and prevailing illicit lelling. m. The University Pinus forest is a mixed forest which has a dense undergrowth and tropical lowland tree species.

In this study, random line sampling method was used to enumerate fauna. Five plots of $100 \mathrm{~m} \times 5 \mathrm{~m}$ each leaving gaps of $50 \mathrm{~m}$, were used as a transect line. Filteen survey lines having 60 plots in the Pinus - mixed forest and 11 survey lines having 51 plots in the natural forest were assigned. The study was restricted to some selected faunal groups such as birds, mammals, reptiles, fishes and some invertebrates (butterflies, land snails etc.). Pitfall trapping was used to assess the diversity of selected ground active invertebrate groups such as ants. beetles and spiders. For each lorest. 10 survey lines were selected and 2 pilfall sampling points were located in each sampling plot for the location of pitfall traps. Two independent samples 1-Test and the Wilcoxon Signed Rank Test were used to compare the launal diversity between the two lorests.

The results showed that there is no significant difference in the diversity of birds, mammals, butterlies, and ground active invertebrates such as ants, beetles and spiders between two forests. The diversity of land snails in the natural forest is significantly higher than the diversity of land snails in the Pinus - mixed forest. The diversity of invertebrates of the Pinus - mixed forest is significantly higher than the natural forest.

According to the results of the present study, the Pinus - mixed forest also has a rich faunal diversity. Therefore, it can be assumed that one or more reasons such as food, nesting places, protection for fauna in the Pinus - mixed forest. edge effects of the surrounding home gardens, and the effect of the rich faunal diversity in the natural have been affected considerably to increase the diversity of some fauna in the Pinus - mixed forest.

Procecelings of the Fouth Anmesl Foresty and Enviromment Symposimm 1998 of the Department of Forestry and Envirenmental Science. University of Sri Jayewardenepara, Sri Lanka 